\title{
Anisotropy of magnetic susceptibility (AMS) studies of Campanian-Maastrichtian sediments of Ariyalur Group, Cauvery Basin, Tamil Nadu, India: An appraisal to Paleocurrent directions
}

\author{
G Papanna ${ }^{1}$, M Venkateshwarlu ${ }^{1, *}, \mathrm{~V}_{\text {Periasamy }}{ }^{1}$ and R Nagendra ${ }^{2}$ \\ ${ }^{1}$ CSIR - National Geophysical Research Institute, Hyderabad 500 00\%, India. \\ ${ }^{2}$ Department of Geology, Anna University, Chennai 600 025, India. \\ *Corresponding author.e-mail: mamila_v@rediffmail.com
}

\begin{abstract}
Oriented samples of sediments from Ariyalur Group, Cauvery Basin, south India, were studied for low field anisotropy of magnetic susceptibility (AMS) measurements to unravel the magnetic fabrics and paleocurrent directions. The results of AMS parameters of the sediments indicate primary depositional fabrics for Sillakkudi, Ottakovil and Kallamedu sandstone formations and secondary fabric for Kallankurichchi limestone formation. The obtained low degree of anisotropy $\left(P_{j}\right)$, oblate shape AMS ellipsoid and distribution of maximum $\left(K_{1}\right)$ and minimum $\left(K_{3}\right)$ susceptibility axes on equal area projection confirm the primary sedimentary fabric for Sillakkudi, Ottakovil and Kallamedu Formations. In the case of ferruginous, lower arenaceous, Gryphaea limestone and upper arenaceous limestone beds of Kallankurichchi Formation have recorded more than one fabric. The observed AMS parameters like shape factor $(T)$ (prolate to oblate), $q$ value and random distribution of minimum $\left(K_{3}\right)$ and maximum $\left(K_{1}\right)$ susceptibility axes are supported for secondary fabrics in Kallankurichchi Formation as a result of post-depositional processes. Based on petrographic studies, it can be established that $K_{1}$ AMS axis of biotite mineral could represent the flow direction. The established paleocurrent direction for Sillakkudi is NW-SE direction while Ottakovil and Kallamedu Formations recorded NE-SW direction. Overall the paleoflow directions observed for Ariyalur Group is NE-SW to NW-SE.
\end{abstract}

\section{Introduction}

The low-field anisotropy of magnetic susceptibility (AMS) technique is increasingly used in geological sciences to study the magnetic fabric in igneous, sedimentary and metamorphic rocks (Nagata 1961; Rees 1965; Ellwood 1980; Knight and Walker 1988; Ernst and Baragar 1992; Tarling and Hrouda 1993; Borradaile and Henry 1997; Cañón-Tapia 2000). Ising (1942) and Graham (1954) were the first to propose the application of AMS in geological studies and since then it has emerged as a successful tool in determining the petrofabric and paleocurrent directions of unconsolidated sediments and sedimentary rocks (Jackson 1991; Schieber and Ellwood 1993; Park et al. 2000; Baas et al. 2007; Parés et al. 2007; Veloso et al. 2007). During the deposition of sediments, the magnetic particles (ferrimagnetic, paramagnetic and diamagnetic) align to ambient geomagnetic field at that time, which is not isotropic and varies with direction, grain size, shape and preferred orientation (Tarling and Hrouda 1993). The results of AMS are usually represented by

Keywords. AMS; magnetic fabric; paleocurrent direction; Cauvery Basin. 
second-rank tensor, which can be depicted as an ellipsoid with mutually perpendicular principle axes, i.e., $K_{1} \geq K_{2} \geq K_{3}$ representing maximum, intermediate and minimum susceptibility axes, respectively (Rochette et al. 1992). The study of magnetic mineralogy and its orientation is a primary step to understand the fabric and paleocurrent directions. The AMS study of sediments (sands and sandstones) is suggested to be a reliable tool to identify the paleoflow directions (e.g., Hamid Reza Bakhtari et al. 1998; Baas et al. 2007). In the past, limestone received less attention in AMS studies than any other sedimentary rock types since their remanent intensities are very weak. Recent development of advanced magnetometers made possible accurate measurement of all weakest remanent magnetizations (Lowrie and Heller 1982). In this study, the preliminary AMS results obtained from the sandstones and limestones of Ariyalur Group of Cauvery Basin, India, have been presented to understand the magnetic fabrics and their paleocurrent directions.

\section{Geological setting}

The Cauvery Basin is a pericratonic basin located along the southeast coast of India (figure 1a). It was developed as a consequence of the breakup of Gondwanaland during the Late Jurassic (Rangaraju et al. 1993). The outcrop area comprises part of the western margin of the basin from Pondicherry in the north to Sivaganga in the south (figure 1b). It includes major outcrop areas at Ariyalur, Vridhachalam and Pondicherry. The Albian to Maastrichtian sedimentary sequences have been divided in ascending stratigraphic order into Uttatur, Trichinopoly and Ariyalur Groups (Blanford 1862), which altogether include seven formations (Tewari et al. 1996; Sundaram et al. 2001).

The Uttatur Group has a maximum thickness of approximately $820 \mathrm{~m}$ and consists of terrestrial, paralic and shallow marine strata. It comprises of lower Dalmiapuram Formation and upper Karai Formation. The former consists of coral algal limestone, bedded limestone and marl, and the later includes variegated shales, veins of gypsum, phosphatic nodules and abundant belemnite casts. The phosphatic nodules, locally known as 'Uttatur potatoes', are normally encased in a chalky shell.

The Trichinopoly Group overlies the Uttatur Group with an angular unconformity. It consists of 490 m thick sediments of Garudamangalam Formation, which is divided into three members, i.e., the Kulakkalnattam sandstone member which is made up of sandstone and clay with shell limestone and calcareous limestone. Anaipadi calcarenite member follows the Kulkkalnattam member, comprises of shale, silt, limestone and sandstone with bands of calcareous grit and the Saturbhagam member in stratigraphic younging. The Garudamangalam Formation is unconformably overlain by the Sillakkudi Formation (Sundaram et al. 2001).

The Ariyalur Group is represented in older to younger stratigraphic order by Sillakkudi, Kallankurichchi, Ottakovil and Kallamedu formations (figure 2). The Sillakkudi sandstone formation of Campanian age consists of well exposed outcrops along the Mettol, Nochikkulam and Vayalpadi areas (figure 1c). The sedimentological studies indicate that the sandstones are mineralogically and texturally immature and poorly sorted. The presence of diverse mollusca, textural maturity and cross lamination indicate that the Sillakkudi sandstone was deposited under shallow marine conditions (Sundaram et al. 2001). This formation is topped by a conglomerate bed exposed at a Kallar stream section. The Kallankurichchi Formation consists of ferruginous limestone, lower arenaceous limestone, Gryphaea limestone, and upper arenaceous limestone (figure 2). The lowermost ferruginous limestone is a fine-to-medium grained massive biomicrite, rich in benthic foraminifera. The lower arenaceous limestone is yellowish in colour, massive, compact, and rich in quartz. The Gryphaea limestone is reddish brown in colour, fine-to-medium grained and rich in carbonate, and the upper arenaceous limestone is rich in quartz. The Kallankurichchi Formation has been deposited under shallow marine, normal saline and well oxygenated, quite to moderate energy conditions with occasional short-lived high energy conditions (Ramkumar 2001, 2004). All the four members of the Kallankurichchi Formation have undergone diagenetic transformations, viz., micritization, compaction, porosity changes, cementation and dolomitization. The presence of Kallar conglomerate between the Kallakuruchchi and Sillakudi Formations indicates a break in deposition during the late Campanian. The Ottakovil Formation consists of coarse-to-medium grained, well sorted, planar to cross bedded sandstone. The rocks contain macrofossils and rare burrow structures, and also show upward fining sequences (figures 1c and 2). The rocks has conformable upper and lower contacts. The lithological and faunal characters indicate deposition of this formation in marginal marine settings in a shallow basin (Ramkumar 2004). The Kallamedu Formation mostly consists of medium-to-coarse grained, bioturbated, massive micaceous sandstones, which are exposed along the stream sections in the eastern part of Kallamedu (figures 1c, 2). The lithology 
(a)
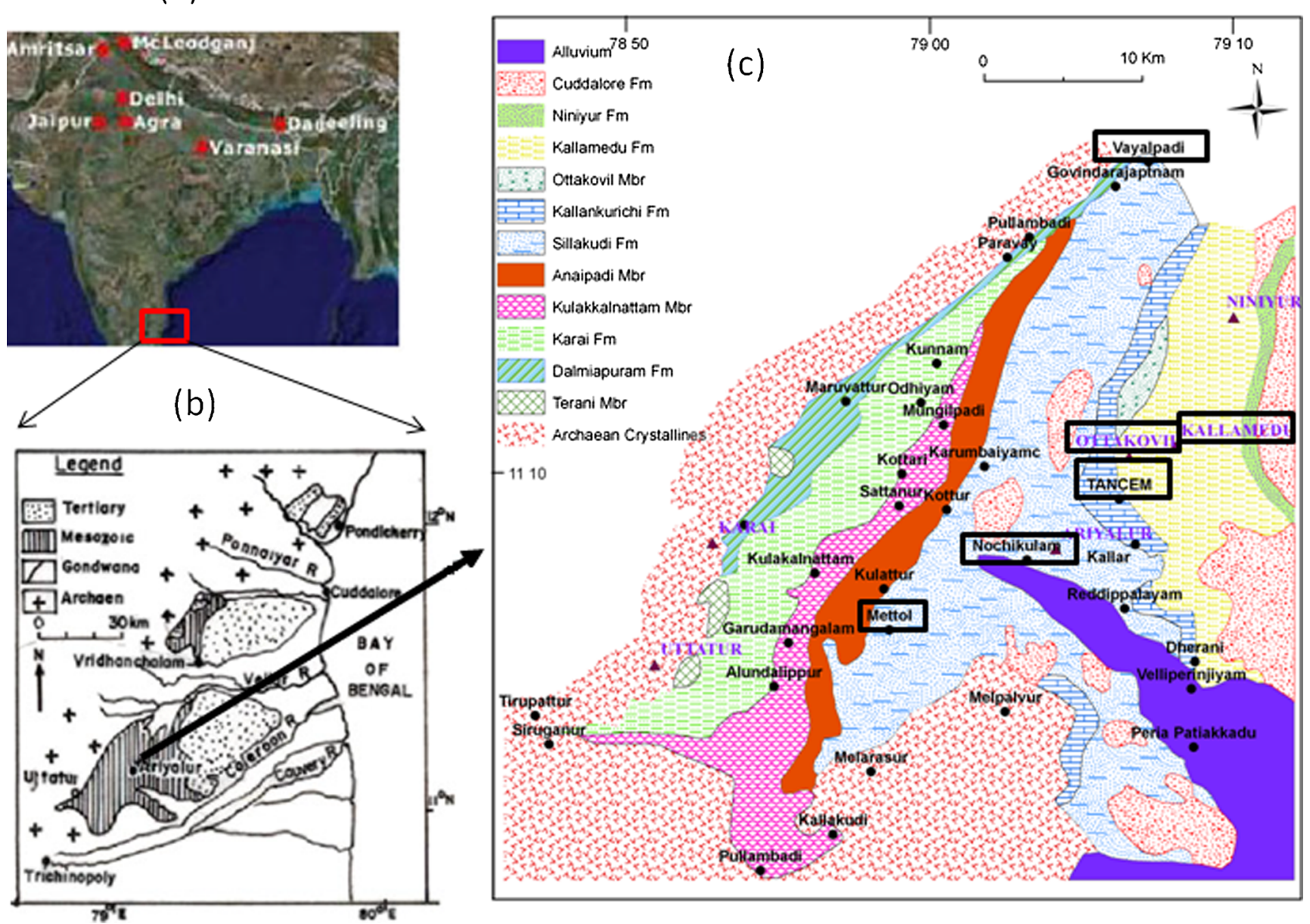

Figure 1. (a) Map of India showing the location of Cauvery Basin, (b) generalized geological map of the Cauvery Basin, (c) detailed geological map of Cauvery basin (after Tewari et al. 1996) showing the sample locations (in black boxes).

of this formation varies from sandstone to siltstone and belongs to Late-Maastrichtian age. The occurrence of cross lamination, scattered macrofossils, and shell concentrations are attributed to shallow marine condition of deposition (Ramkumar 2004; Ramasamy et al. 2012).

\section{Anisotropy of magnetic susceptibility (AMS)}

The magnetic fabric in sedimentary rocks can develop during deposition (primary fabric) and even after deposition (secondary fabrics) of the sediments as a result of bioturbation, compaction and tectonic disturbances (Rees 1961). The first factor that controls the primary fabric of sediments is gravity settling, which results in the random orientation of long and intermediate axes of the grains parallel to the depositional surface. The second important factor is water current, which tends to align the long axis of grains parallel to the flow direction at low-to-moderate current (Tarling and Hrouda 1993; Piper et al. 1996; Liu et al. 2001; Parés et al. 2007). However, if the hydrodynamic force is strong enough, the long axis will turn to oblique or perpendicular to current direction (Hamilton and Rees 1970) resulting in the development of lineation. Generally, the orientations of AMS $K_{\max }$ and $K_{\min }$ axes of grains are aligned by the direction of water current, and the plots of two axes in stereographic projection reflect paleocurrent directions (Hrouda 1982; Lowrie and Hirt 1987; Taira 1989; Rochette et al. 1992; Sangode 2001; Rathi et al. 2007). The AMS parameters used in the present study are shown in table 1.

The magnetic susceptibility $(K)$ of the rock sample is obtained when it is subjected to induced magnetization $(J)$ by an applied field $(H)$ following the formula $J=k H$. The mean susceptibility 


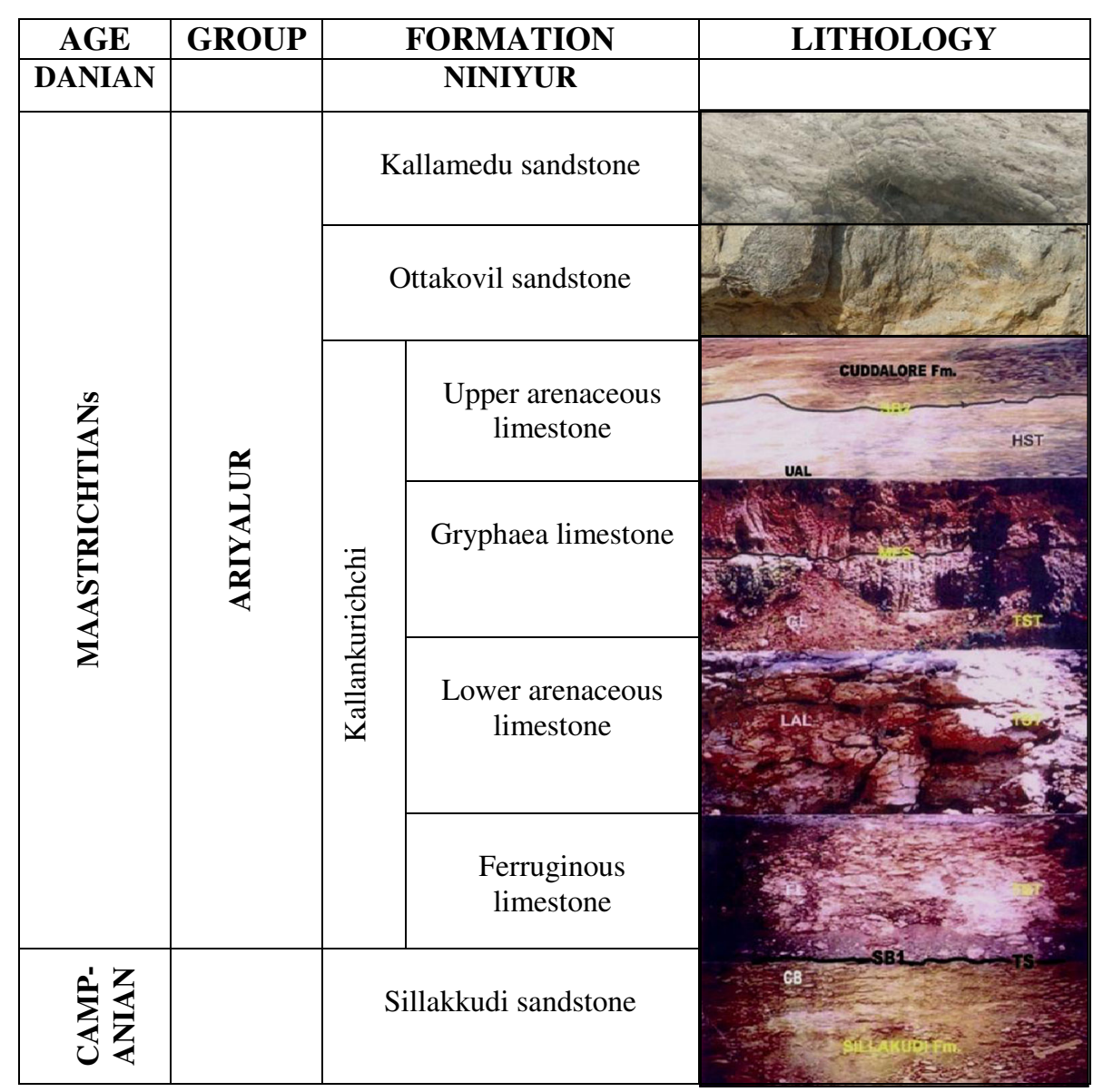

Figure 2. Lithostratigraphic succession showing different litho units of Ariyalur Group of Cauvery Basin.

Table 1. AMS parameters measured in this study.

\begin{tabular}{lcl}
\hline Parameter & Formula & \multicolumn{1}{c}{ Reference } \\
\hline Mean susceptibility & $K_{m}=\left(K_{1}+K_{2}+K_{3}\right) / 3$ & Nagata (1961) \\
Foliation & $F=K_{2} / K_{3}$ & Stacey et al. (1960) \\
Lineation & $L=K_{1} / K_{2}$ & Balsley and Buddington (1960) \\
Shape factor & $T=\left(2 \eta_{2}-\eta_{1}-\eta_{3}\right) /\left(\eta_{1}-\eta_{3}\right)$ & Jelinek (1981) \\
-factor & $q=\left(K_{1}-K_{2}\right) /\left(0.5\left(K_{1}+K_{2}\right)-K_{3}\right)$ & Granar (1958) \\
$\begin{array}{l}\text { Corrected anisotropy } \\
\text { degree }\end{array}$ & $P_{j}=\exp \sqrt{2\left[\left(\eta_{1}-\eta_{m}\right)^{2}+\left(\eta_{2}-\eta_{m}\right)^{2}+\left(\eta_{3}-\eta_{m}\right)^{2}\right]}$ & Jelinek $(1981)$ \\
\hline
\end{tabular}

$K_{1}$, maximum; $K_{2}$, intermediate; $K_{3}$, minimum susceptibility axes.

$\eta_{1}=\ln K_{1} ; \eta_{2}=\ln K_{2} ; \eta_{3}=\ln K_{3} ; \eta_{m}=\sqrt[3]{\eta_{1} \cdot \eta_{2} \cdot \eta_{3}}$

$\left(K_{m}\right)$ is calculated by the formula given in table 1 . The directions of susceptibility axes are presented on the lower hemisphere of the equal area projection. The magnetic foliation $(F)$ is developed when the magnetic particles or platy minerals are arranged with their shortest and longest AMS axes in perpendicular and parallel to bedding plane, respectively. The lineation $(L)$ is developed when the $K_{\max }$ axes of particles are arranged parallel to the water current; however, perpendicular or oblique arrangements are also common. Generally, two shape parameters $T(-1 \geq T \geq 1)$ are known for the susceptibility ellipsoids. When $T<0$, the shape of the ellipsoid is prolate (rod 
shaped), and if $T>0$, the ellipsoid is oblate (disc shaped). The other parameter is called $q$-factor, which is commonly used to distinguish the nature of fabric development, viz., either depositional or tectonic fabric (Hamilton and Rees 1970). Usually the $q$ values ranging between 0.06 and 0.7 indicate primary depositional fabric, and $q>0.7$ indicates tectonic fabric. The eccentricity and shape of susceptibility ellipsoid are represented graphically by Flinn plot, in which magnetic foliation $(F)$ and magnetic lineation $(L)$ are plotted on $\mathrm{x}$ and $\mathrm{y}$ axes, respectively.

\section{Sampling and methods}

Forty six oriented sediment block samples were collected from 7 sites (mines, railway cuttings and river channel cuttings) covering the total thickness $(\sim 40 \mathrm{~m})$ of the exposed rocks of Ariyalur Group (figure 1c). All the samples were drilled and cut into standard specimens $(2.2 \mathrm{~cm}$ length and $2.5 \mathrm{~cm}$ diameter) and measured in the Paleomagnetism Laboratory of National Geophysical Research Institute, Hyderabad, India, following the standard procedures described by Jelinek (1978). A total of 233 specimens were made out of 46 samples from Sillakkudi sandstone (33), Ferruginous limestone (20), Lower arenaceous limestone (42), Gryphaea limestone (35), Upper arenaceous limestone (34), Ottakovil sandstone (32), and Kallamedu sandstone (37). The samples were subjected to AMS measurements in 15 different directions using Kappa Bridge MFK1-FA (Brno, Czech Republic) susceptibility meter following the standard method as per Agico user's guide ver-4 2009. Since the beds were undisturbed, no tilt correction was made.

\section{Petrography}

A total of 20 thin sections representing all the formations of Ariyalur Group were studied to know the petrographic characters of the rocks under study (figure 3). Petrographic studies of Sillakkudi Formation show moderate-to-well sorted, fine-tomedium grained and poorly indurated arkosic sandstone, cemented by calcareous material. Quartz is the dominant framework grain with minor amount of alkali feldspar cemented with calcite matrix. Abundance of biotite flakes were observed in thin section with preferred orientation (figure 3a). The abundance of feldspar, especially plagioclase, indicates rapid deposition from a nearby granitic/gneissic provenance (Nagendra et al. 2003). Figure 3(b, c and d) are the micro- photographs of Kallankurichchi Formation consist predominantly of skeletal and fragmental limestone from bank and bank derived material. The Ottakovil Formation is a medium-to-coarse grained rock, consisting of Quartz with minor K-feldspar and lithic fragments with carbonate matrix (figure 3e). Figure 3(f) shows the microphotograph of the Kallamedu sandstone consisting of few haematite specks cemented within calcareous matrix.

\section{Results}

\subsection{Isothermal Remanent Magnetization (IRM)}

The IRM study for selected samples from the Ariyalur Group was carried out in order to know their magnetic mineralogy using MMPM 10 pulse magnetizer in forward and back-field magnetization. Figure 4 shows the IRM acquisition curves for all the four formations. The obtained IRM curves from the Sillakkudi, Ottakovil and Kallamedu sandstone samples show that the magnetization fields are not saturated till 3T applied magnetic field (figures 4a, c and d) depicting the presence of hematite $\left(\mathrm{Fe}_{2} \mathrm{O}_{3}\right)$ as primary magnetic carrier. It is the same in case of Kallankurichchi limestone where the saturation of magnetization is not acquired till 3T (figure 4b). From this study, it could be concluded that the major magnetic remanent carrier in all these formations is hematite $\left(\mathrm{Fe}_{2} \mathrm{O}_{3}\right)$. However, apart from ferrimagnetic minerals, the paramagnetic minerals also contribute to the total AMS and magnetic fabric (Hounslow 1985; Rochette and Filliong 1988). In the samples of Sillakkudi, Ottakovil, and Kallamedu formations the important paramagnetic mineral observed under microscope is biotite, which could determine the magnetic fabric.

\subsection{Analyses of AMS parameters}

The selective AMS parameters, e.g., mean magnetic susceptibility $\left(K_{m}\right)$, corrected anisotropy degree $\left(P_{j}\right)$, magnetic lineation $(L)$, magnetic foliation $(F)$, and ellipsoid shape $(q)$ (after Jelinek 1981; Ellwood and Crick 1988; Tarling and Hrouda 1993) of our studied sample population are presented in table 2 . The overall calculated mean susceptibility is ranging from $4.57 \times 10^{-5}$ to $2.57 \times$ $10^{-4}$ SI units with the average value of $1.21 \times$ $10^{-4}$ SI units suggesting the presence of paramagnetic particles. The obtained minimum, maximum and average values for lineation are 1.006, 1.018 and 1.012 , and for foliation are 1.006, 1.025 and 1.018 , respectively. The anisotropy degree $\left(P_{j}\right)$ 

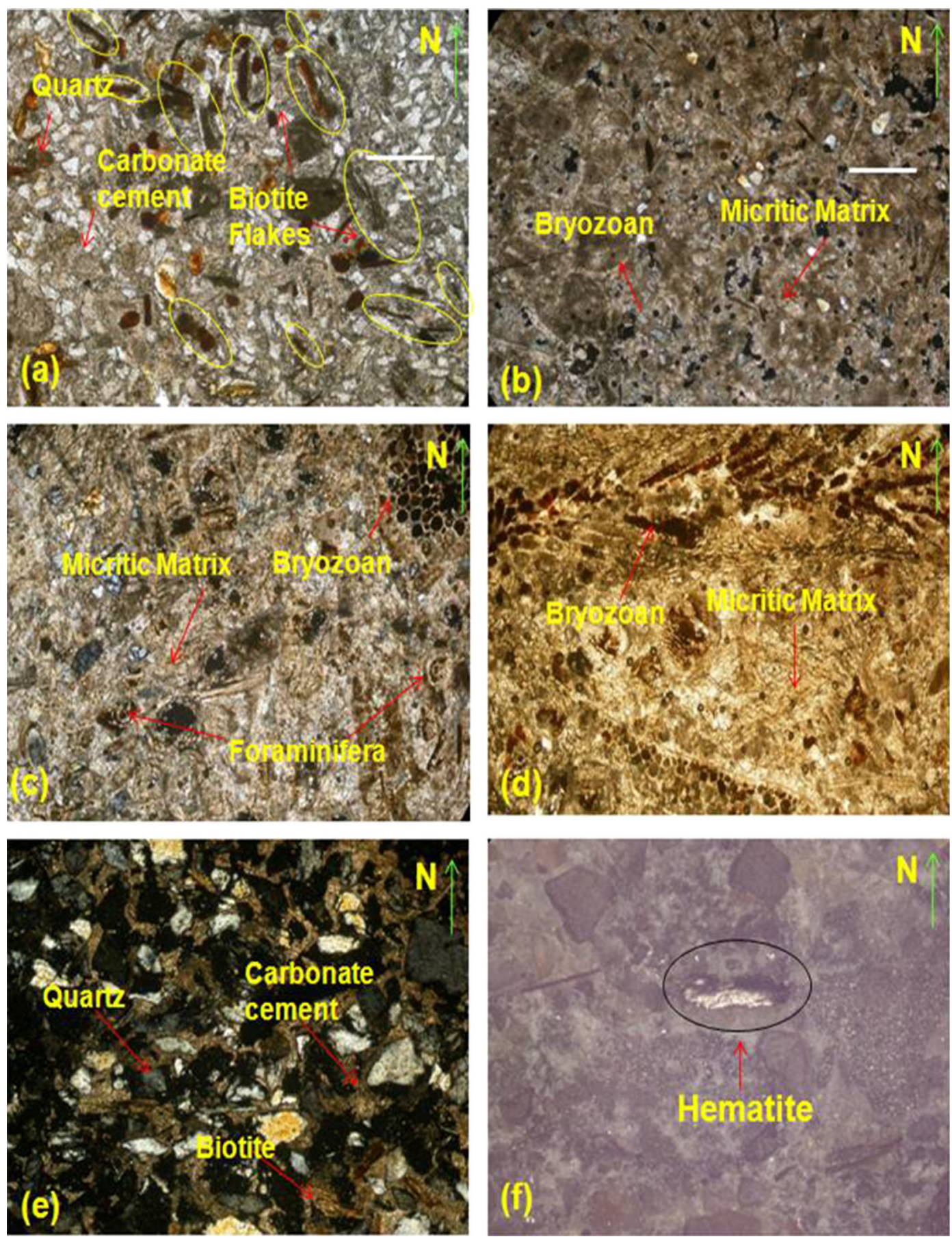

Figure 3. Microphotographs prepared on oriented horizontal plane with marked north direction helped to infer the paleoflow direction. (a) Sillakkudi sandstone showing the oriented biotite flakes (yellow elliptic marking), (b) micritized limestone with little terrigenous input, (c) and (d) show cement spars and intra particle porosity with remains of foraminifera, corals and bryozoa, (e) Ottakovil sandstone with well observed biotite minerals, and (f) Kallamedu sandstone shows hematite mineral (black elliptic marking) in reflected light mode. Scale bar $=0.5 \mathrm{~mm}$.

varies from 1.012 to 1.043 with average value of 1.031. The results of $K_{m}, P_{j}, F, L$ and $T$ values show distinct variations for different stratigraphic units (figure 5). The highest mean value of magnetic susceptibility $\left(K_{m}\right)$ is observed in Sillakudi sandstone, while the lowest is in lower arenaceous limestone of Kallankurichchi Formation. The values of degree of anisotropy $\left(P_{j}\right)$ and lineation $(L)$ show minor variations vertically in stratigraphic succession; however, significant low is observed for the ferruginous limestone. The Sillakudi sandstone has the maximum value of $T$. 



Figure 4. IRM acquisition curves for (a) Sillakkudi Formation (Fm), (b) Kallankurichchi Fm, (c) Ottakovil Fm, and (d) Kallamedu Fm. Note that the saturation is not achieved even at higher fields (up to $3 T$ ) indicating the presence of hematite as primary magnetic mineral in all samples.

Table 2. Calculated AMS parameters of samples of Ariyalur Group, Cauvery Basin, India. $K_{1}, K_{2}$ and $K_{3}=$ maximum, intermediate and minimum $A M S$ axes, $D / I=$ declination/inclination, $K_{m}=$ mean susceptibility in $S I$ units. $P_{j}, F$ and $L=$ anisotropy degree, foliation and lineation, $T$ and $q$ are shape parameters, for explanation see table 1.

\begin{tabular}{|c|c|c|c|c|c|c|c|c|c|c|}
\hline Formations & $\begin{array}{c}\text { No. of specimens } \\
\text { measured/ } \\
\text { calculated }\end{array}$ & $K_{1}(D / I)$ & $K_{2}(D / I)$ & $K_{3}(D / I)$ & $K_{m}$ & $P_{j}$ & $F$ & $L$ & $T$ & $q$ \\
\hline Kallamedu & $37 / 18$ & $39.9 / 0.1$ & $129.9 / 1.0$ & $305 / 89$ & $9.82 \mathrm{E}-05$ & 1.034 & 1.023 & 1.009 & 0.429 & 0.04 \\
\hline Ottakovil & $32 / 26$ & $193.2 / 4.2$ & $103.2 / 0.3$ & $8.6 / 85.7$ & $1.61 \mathrm{E}-04$ & 1.033 & 1.024 & 1.006 & 0.56 & 0.07 \\
\hline \multicolumn{11}{|l|}{ Kallankurichchi } \\
\hline $\begin{array}{l}\text { Upper arenaceous } \\
\text { limestone }\end{array}$ & 34 & $124 / 3.7$ & $215.2 / 18.6$ & $23.2 / 71$ & $8.29 \mathrm{E}-05$ & 1.027 & 1.014 & 1.013 & 0.035 & 0.67 \\
\hline Gryphaea limestone & 35 & 291.9/17.3 & $23.3 / 4.5$ & $127.3 / 12$ & $8.49 \mathrm{E}-05$ & 1.036 & 1.02 & 1.014 & 0.264 & 0.40 \\
\hline $\begin{array}{l}\text { Lower arenaceous } \\
\text { limestone }\end{array}$ & 42 & $283.9 / 3.8$ & $193.8 / 1.5$ & $81.8 / 85.9$ & $4.57 \mathrm{E}-05$ & 1.041 & 1.021 & 1.018 & 0.046 & 0.67 \\
\hline $\begin{array}{l}\text { Ferruginous } \\
\text { limestone }\end{array}$ & 20 & $37.2 / 12.1$ & $128.3 / 5.2$ & $240.9 / 76.8$ & $1.32 \mathrm{E}-04$ & 1.012 & 1.006 & 1.006 & 0.043 & 1.33 \\
\hline Sillakkudi & $33 / 21$ & $30.6 / 4.9$ & $120.7 / 0.7$ & $219.2 / 85$ & $2.51 \mathrm{E}-04$ & 1.031 & 1.024 & 1.004 & 0.64 & 0.04 \\
\hline
\end{tabular}




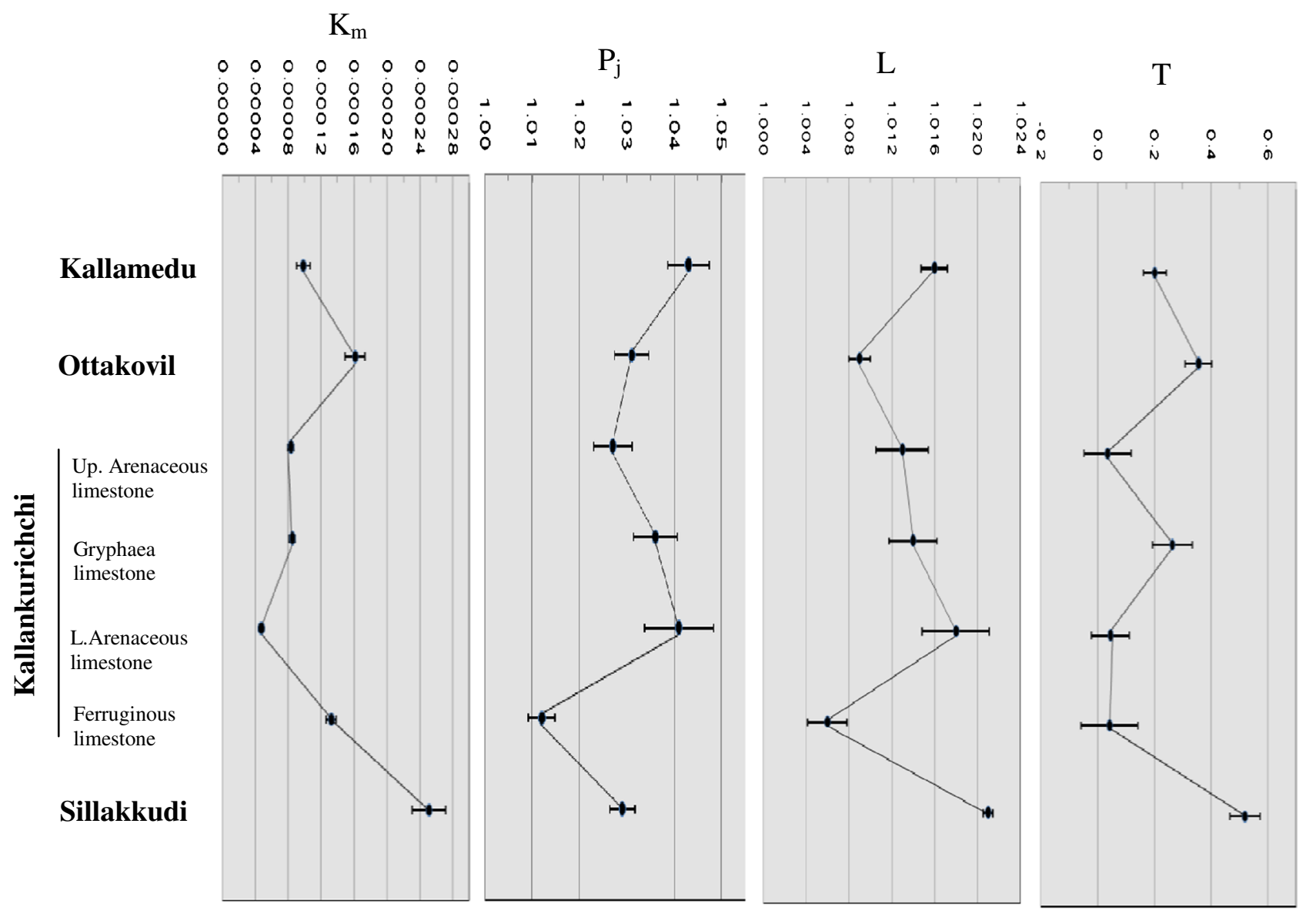

Figure 5. AMS parameters drawn for all the formations. Magnetic susceptibility $\left(K_{m}\right)$, degree of anisotropy $\left(P_{j}\right)$, lineation $(L)$ and shape factors $T$ are showing distinct changes on each formation with standard error bars (error symbols are $2 \sigma$ confidence level).

The calculated mean susceptibility and anisotropy degree $\left(P_{j}\right)$ of Sillakkudi Formation is $2.57 \times 10^{-4}$ SI units and 1.03, respectively. Figure 6(i-iii) shows the distribution of maximum $\left(K_{1}\right)$, intermediate $\left(K_{2}\right)$ and minimum $\left(K_{3}\right)$ susceptibility axes and Flinn diagram $(L$ vs. $F) . K_{3}$ axis clustered on pole while $K_{1}$ falls on horizontal plane in stereo projection diagram; however, minor grouping of $K_{1}$ axis is observed in $\mathrm{NE}$ quadrant (figure 6A). The average values of $F$ and $L$ are 1.024 and 1.004, while the values of individual samples plotted in Flinn diagram fall in oblate shape ellipsoid portion (figure 6a) and its $q$ value is 0.1 .

In the Kallankurichchi Formation, the mean susceptibilities $\left(K_{m}\right)$ for the ferruginous limestone, lower arenaceous limestone, Gryphaea limestone and upper arenaceous limestone are $1.32 \times 10^{-4}$, $4.57 \times 10^{-5}, 8.49 \times 10^{-5}$ and $8.29 \times 10^{-5} \mathrm{SI}$ units, respectively. The $T$ values of all the four rock units ensure oblate to prolate shape ellipsoids with the values of $0.035,0.264,0.046$ and 0.048 , respectively. Another shape factor $q$ for ferruginous limestone, lower arenaceous limestone, and upper arenaceous limestone show the values close to 0.7 , while Gryphaea limestone has 0.4. Figure 6(B-E) show the stereoplot of three susceptibility axes for ferruginous limestone, lower arenaceous limestone, Gryphaea limestone, and upper arenaceous limestone, respectively, which reveal that the directions of $K_{1}, K_{2}$ and $K_{3}$ axes are scattered due to the post-depositional processes or the imprints of more than one fabric (Lowrie and Heller 1982). From the plotted Flinn diagram, it is observed that $50 \%$ of the samples show prolate shape AMS ellipsoid and the rest indicate oblate shape ellipsoid (figure $6 \mathrm{~b}-\mathrm{e}$ ).

The values of $K, P_{j}, F$ and $L$ for Ottakovil Formation are $1.61 \times 10^{-4}$ SI units, 1.033, 1.024 and 1.006, respectively. The shape parameters confirmed the oblate shape with positive value of 0.558 for $T$ and 0.07 for $q$. The distribution of three anisotropic susceptibility axes is shown in figure $6(\mathrm{~F})$, in which the $K_{1}$ axis falls on bedding plane in stereographic projection, while $K_{3}$ is clustered on pole indicating well developed cleavage plane. All the measured samples plotted in Flinn diagram show oblate shape ellipsoid 



Figure 6(i-iii). Distribution of maximum $\left(K_{1}\right)$, intermediate $\left(K_{2}\right)$ and minimum $\left(K_{3}\right)$ susceptibility axes for measured samples (a) Sillakkudi, (b) ferruginous limestone, (c) lower arenaceous limestone, (d) Gryphaea limestone, (e) upper arenaceous limestone, (f) Ottakovil and (g) Kallamedu formations. Figure 6(a-g) represents Flinn diagram $(L$ vs. $F)$. 
(D)

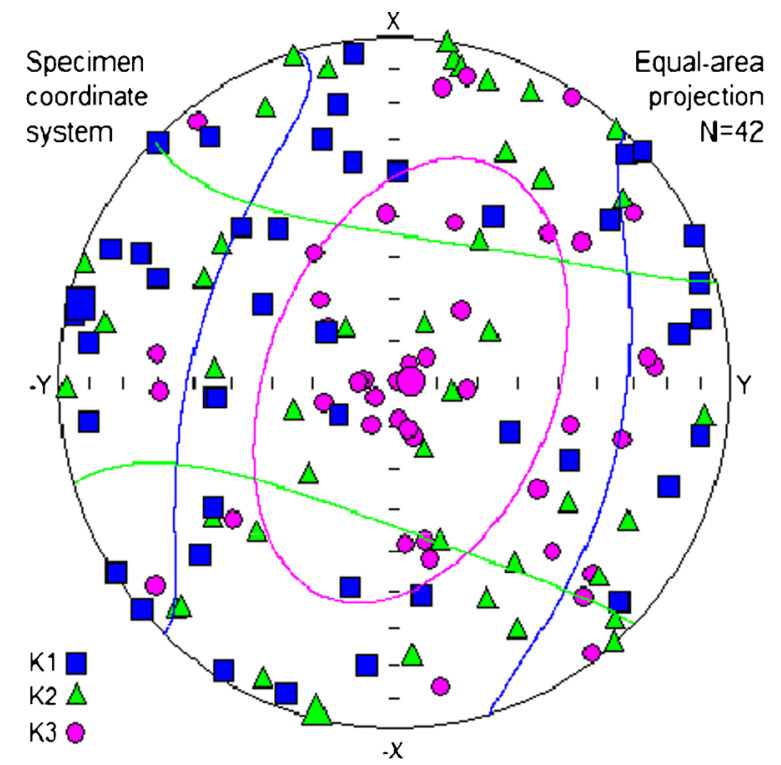

(E)

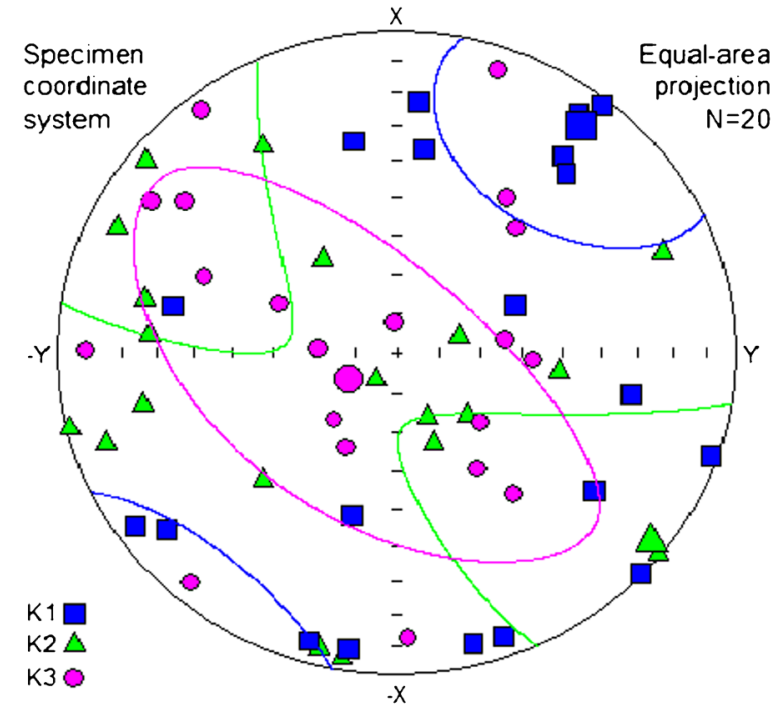

(F)

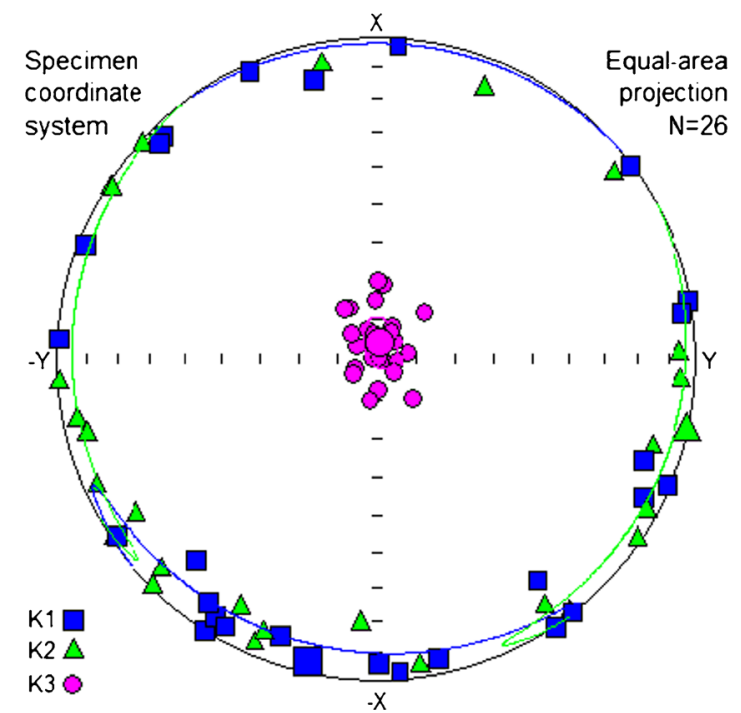

(d)

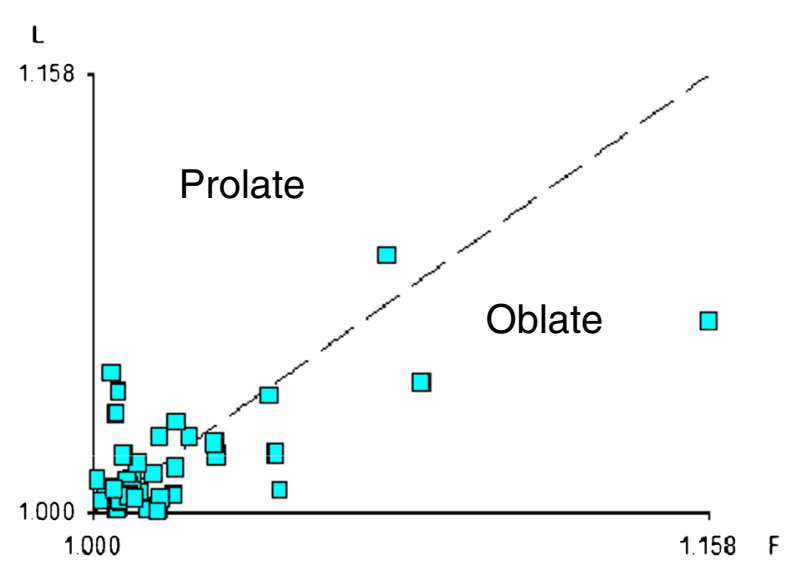

(e)



(f)

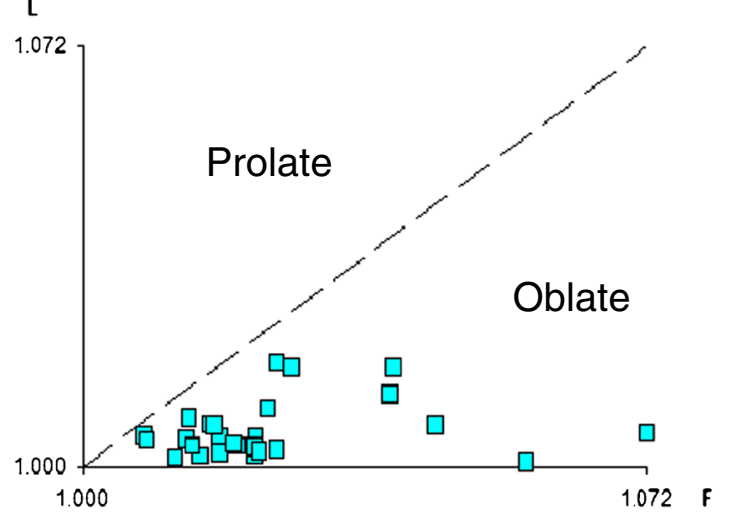

Figure 6. (Continued.) 


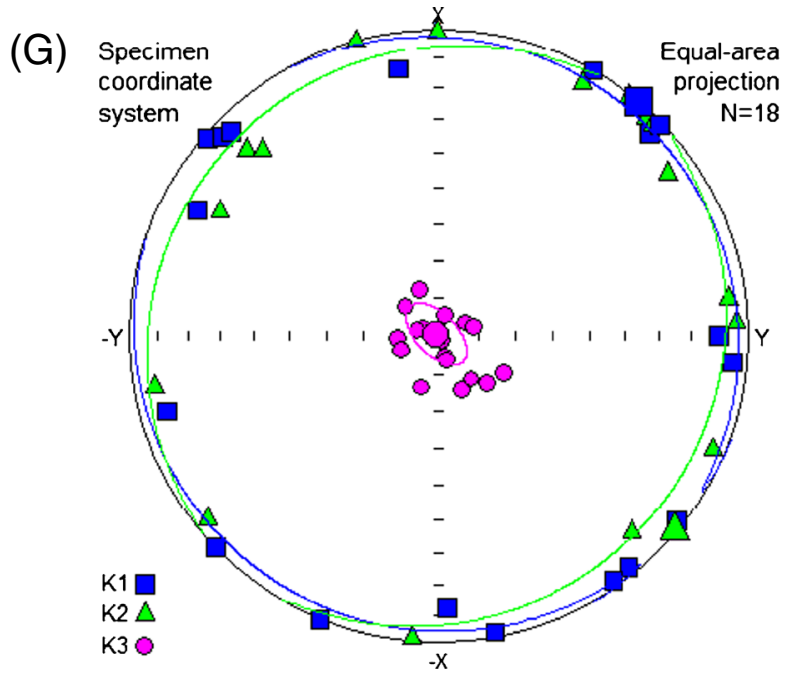

(g) $\mathrm{L}$

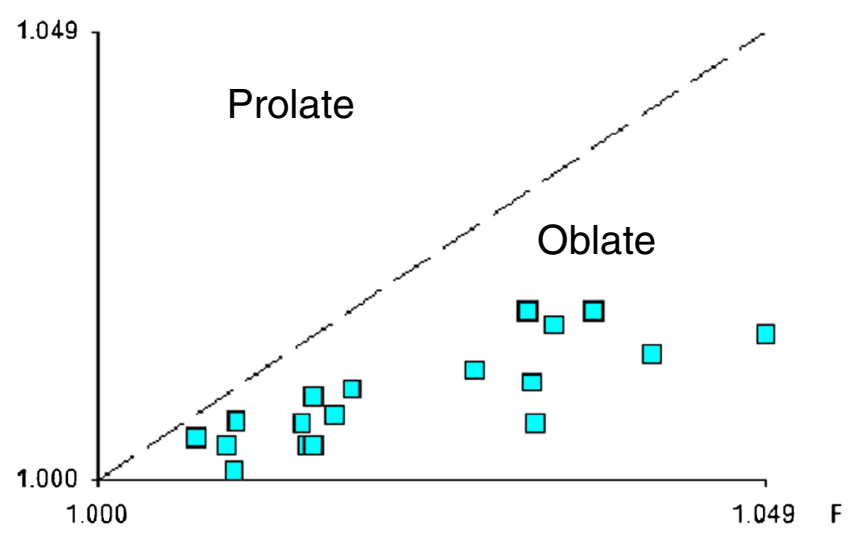

Figure 6. (Continued.)

(figure 6f). The calculated mean susceptibility $\left(K_{m}\right)$ for Kallamedu Formation is $9.82 \times 10^{-5}$ SI unit. The degree of anisotropy $\left(P_{j}\right)$ has the value of 1.034 showing oblate anisotropy ellipsoid with $T$ value $>0$, and the other shape factor $(q)$ also indicates oblate with the value of 0.2 . The observed magnetic foliation $(F)$ and lineation $(L)$ are 1.023 and 1.009, respectively. The $K_{1}, K_{2}$ and $K_{3}$ values of Kallamedu Formation are plotted in equal area stereographic projection (figure 6G) which shows that the maximum $\left(K_{1}\right)$ susceptibility axis lies parallel to bedding plane, while minimum $\left(K_{3}\right)$ axis is grouped on pole indicating the oblate shape magnetic fabrics. The Flinn diagram ( $L$ versus $F$ ) drawn from the values of lineation and foliation shows that all the samples are plotted in oblate field (figure 6g).

\section{Discussion}

\subsection{Magnetic fabrics}

Majority of biotite flakes in the Sillakudi Formation (figure 3a) are identified in preferred orientation which could control magnetic fabrics and can be used as a paleocurrent indicator (Borradaile and Henry 1997). Well developed foliation plane has been observed as the minimum susceptibility axis $\left(K_{3}\right)$ is well grouped on poles, and $K_{1}$ axis falls on bedding plane in stereographic projection (figure 6a) with less developed lineation $(L) . T$ value of 0.64 depicts oblate shape fabric; the Flinn plot also ensured the oblate shape ellipsoid with all the specimens scattered in oblate portion (figure 6a).

The investigated samples from all the four beds of Kallankurichchi limestone Formation proved to be suitable for magnetic fabric studies as it has mean susceptibility values ranging from $8.29 \times 10^{-5}$ to $1.32 \times 10^{-4} \mathrm{SI}$ units (table 2 ). The secondary processes can produce unexpected AMS axes orientation as a result of total disruption of primary processes or the combination of more than one fabric as normal, inverse or mixed (Rochette et al. 1992). Based on the observations of figure 6(b-e), the results of scattered $K_{1}, K_{2}$ and $K_{3}$ axes on stereographic projection could be attributed to the post-depositional processes. The shape factor $T$ indicates transformation of oblate to prolate fabric and the same is observed in Flinn plot also for all the four beds (figure $6 \mathrm{~b}-\mathrm{e}$ ).

From IRM study, the magnetic mineral identified for Ottakovil Formation is hematite. The value of $q=0.077$ infers the primary depositional fabric. The distribution of $K_{1}, K_{2}$ and $K_{3}$ axes indicate clear oblateness with minimum axis $\left(K_{3}\right)$ grouped on pole and maximum axis $\left(K_{1}\right)$ dispersed within horizontal plane; however, the $K_{3}$ axis trends $\mathrm{N}-\mathrm{S}$ direction with a minor dipping (figure 6f). The nature of fabric developed in this formation is oblate (disc shaped) with the $T$ value at 0.558 . The plot $L$ versus $F$ (figure 6 f) showing strong oblateness of fabric.

However, in the petrographic studies the dominance of biotite is observed while hematite was identified in reflectance microscope. Hence, the magnetic fabric in this formation is believed to have developed from the contribution of both hematite (ferromagnetic mineral) and biotite (paramagnetic mineral). The values of magnetic susceptibility for paramagnetic minerals are generally low and around $5 \times 10^{-4}$ SI units (Tarling and Hrouda 1993). For Kallamedu Formation, the obtained average value of susceptibility is $9.823 \times 10^{-5}$ SI units which confirm the 

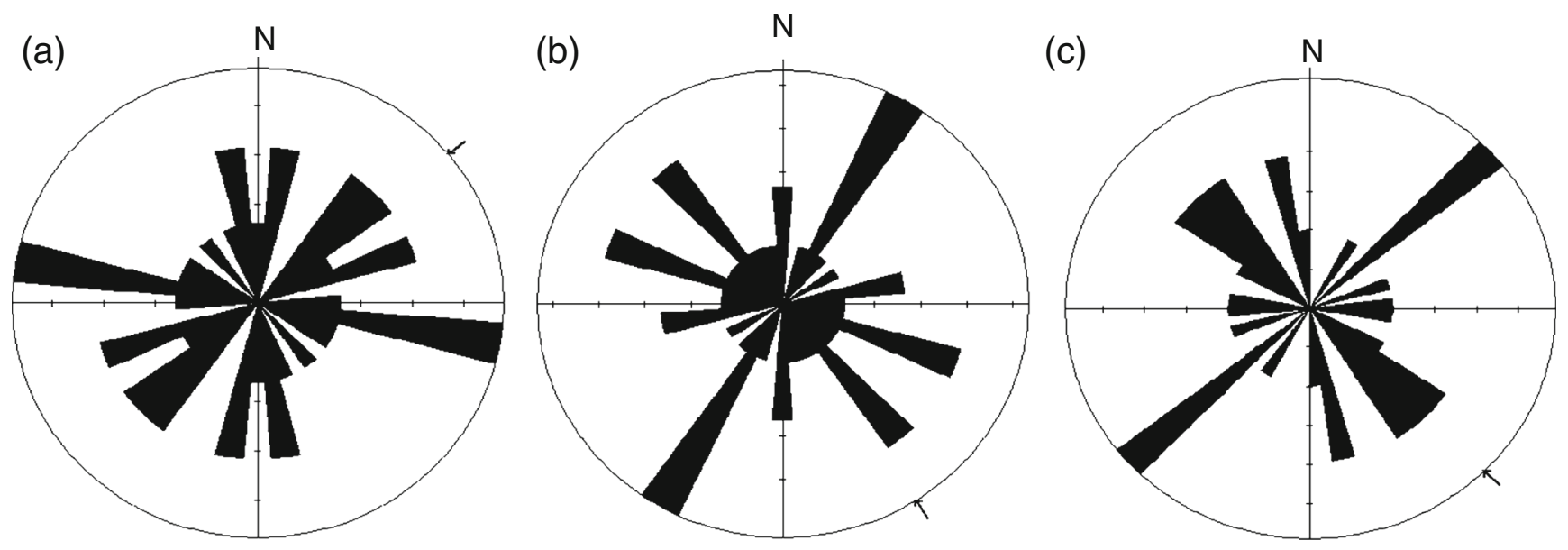

Figure 7. Rose diagram drawn from declination and inclination of $K_{1}$ axis shows the paleocurrent directions for Sillakkudi (a), Ottakovil (b) and Kallamedu (c) Formations.

paramagnetic contribution. Our AMS results infer that Kallamedu Formation shows oblate ellipsoid and primary depositional sedimentary fabric as the shape factor $T$ has the value of 0.43 while $q$ value is in-between 0.06 and 0.7. Measured AMS parameters, i.e., T, Flinn plot, and distribution of $K_{1}, K_{2}$ and $K_{3}$ axes confirmed the oblate shape magnetic fabrics while $q$ value indicates primary depositional fabric (figure 6g).

\subsection{Construction of Paleocurrent directions}

In this study, the distribution of $K_{1}$ axes of magnetic anisotropy is used to estimate the paleoflow directions since it is supported by petrofabric analysis. The paleocurrent directions for Sillakkudi, Ottakovil and Kallamedu Formations were established based on petrographic studies and available literature sources. As discussed earlier the arrangement of biotite mineral could be used to deduce the paleocurrent directions as the platy nature of these minerals allows them to be aligned easily due to prevailing water currents (Rathi et al. 2007). The available paleoflow directions for these formations based on primary sedimentary structures, i.e., scour structures, channel orientation, etc., suggest N-S orientation (Tewari et al. 1996; Ramkumar 2004); however, in this study, slight imbrication is observed in thin sections. Therefore, petrofabric and macroscopic sedimentary structures proved that $K_{1}$ axis could be used to establish the paleoflow direction. Figure 7 shows the rose diagram drawn from declination and inclination of maximum susceptibility axis $\left(K_{1}\right)$ as an indication of paleocurrent direction, while other axes are not coinciding with micaceous mineral orientation and macroscopic structures.
Based on abovementioned factors, the flow direction obtained for Sillakkudi Formation is NWSE (figure 7a). Although oblate fabric suggests that the flow could be random for this formation, the biotite arrangement observed in thin section proved that the paleoflow direction is NWSE. But the current strength inferred is low for Sillakudi Formation; otherwise the $K_{1}$ axis of biotite flakes could be turned perpendicular to the current direction (Tarling and Hrouda 1993). The paleocurrent directions observed for both Ottakovil and Kallamedu Formations are NE-SW (figure 7b and c). Estimation of paleocurrent direction for Kallankurichchi limestone is very poor since these beds have no recorded directions due to secondary magnetic fabrics produced by later processes.

In this study, it is revealed that for Ariyalur Group of Cauvery Basin, sandstone formations are more reliable in paleocurrent estimation than the limestone formations by AMS analysis.

\section{Conclusions}

From this study, the following conclusions can be drawn.

- The IRM results infer that the magnetic mineralogy for the sediments of Sillakkudi, Kallankurichchi, Ottakovil, and Kallamedu Formations is controlled by hematite $\left(\mathrm{Fe}_{2} \mathrm{O}_{3}\right)$.

- The magnetic fabrics of sandstone formations of Ariyalur Group are developed by primary depositional processes and limestone formations by secondary processes.

- The reconstructed paleoflow direction for Sillakkudi Formation is NW-SE and for Ottakovil and Kallamedu is NE-SW. 
It is highly recommended that further detailed studies on magnetic separates like ferrimagnetic, paramagnetic and matrix mineral contribution to the development of magnetic fabric and to the total AMS analysis is required for further understanding of the nature of magnetic fabric in Cauvery Basin.

\section{Acknowledgements}

The authors are thankful to the Director, CSIRNGRI for necessary permission for publishing this paper. Authors thank Dr S Misra and an anonymous reviewer for their valuable and constructive suggestions. Authors thank the Department of Science and Technology, New Delhi for the financial assistance (No. SR/S4/ES-271/2007). One of the authors (GP) is benefitted by Rajiv Gandhi National Fellowship (No. F 14-2(ST) 2010 (SAIII)/2011).

\section{References}

Agico KLY-3 User's Guide 2009 AGICO Advanced Geoscience Instruments CO; 4. Brno, Czech Republic.

Baas J H, Hailwood E A, McCaffrey W D, Kay M and Jones R 2007 Directional petrological characterization of deep-marine sandstones using grain fabric and permeability anisotropy: Methodologies, theory, application and suggestions for integration; Earth Sci. Rev. 82 101-142.

Balsley J R and Buddington A F 1960 Magnetic susceptibility anisotropy and fabric of some Adirondack granites and orthogneisses; Am. J. Sci. 258-A 6-20.

Blanford H F 1862 Cretaceous and other rocks of South Arcot and Trichinopoly districts, Madras; Geol. Surv. India Memoir 4(1) 217.

Borradaile G J and Henry B 1997 Tectonic application of magnetic susceptibility and its anisotropy; Earth Sci. Rev. 42 49-93.

Cañón-Tapia E 2000 The anisotropy of magnetic susceptibility of lava flows: An experimental approach; J. Volcanol. Geotherm. Res. 98 219-233.

Ellwood B B 1980 Application of the anisotropy of magnetic susceptibility method as an indicator of bottom water flow direction; Mar. Geol. 34 83-90.

Ellwood B B and Crick R E 1988 Paleomagnetism of Paleozoic asphaltic deposits in southern Oklahoma, USA; Geophys. Res. Lett. 15 436-439.

Ernst R E and Baragar W R A 1992 Evidence from magnetic fabric for the flow pattern of magma in the Mackenzie giant radiant dyke swarm; Nature 356 511-513.

Graham J W 1954 Magnetic susceptibility anisotropy, an unexploited petrofabric element; Geol. Soc. Am. Bull. 65 1257-1258.

Granar L 1958 Magnetic measurements on Swedish varved sediments; Arkiv. F. Geofusik. 3 1-40.

Hamid Reza Bakhtari, Dominique F Le, Charles Aubourg and Jamshid Hassanzadeh 1998 Magnetic fabrics of Tertiary sandstones from the Arc of Fars (Eastern Zagros, Iran); Tectonophys. 284 299-316.

Hamilton N and Rees A I 1970 The use of magnetic fabric in palaeocurrent estimation; In: Palaeogeophysics (ed.) Runcorn S K (London: Academic Press), pp. 445-464.
Hounslow M W 1985 Magnetic fabric arising from paramagnetic phyllosilicate minerals in mud rocks; J. Geol. Soc. London 142 995-1006.

Hrouda F 1982 Magnetic anisotropy of rocks and its application in geology and geophysics; Geophys. Surv. 5 37-82.

Ising G 1942 On the magnetic properties of varved clay. Ark. Mat; Astr. Phys. 29 1-37.

Jackson M J 1991 Anisotropy of magnetic remanence a brief review of mineralogical sources, physical origins and geological applications, and comparison with susceptibility anisotropy; Pure Appl. Geophys. 136 1-28.

Jelinek V 1978 Statistical processing of anisotropy of magnetic susceptibility measured on groups of specimens; Studia Geo-physica et Geodetica 22 50-62.

Jelinek V 1981 Characterization of the magnetic fabric of rocks; Tectonophys. $\mathbf{7 9} 63-67$.

Knight M D and Walker G P L 1988 Magma flow directions in Dikes of the Koolau Complex, Oahu, determined from magnetic fabric studies; J. Geophys. Res. 93 (B5) 4301-4319.

Liu B, Saito Y, Yamazaki T, Abdeldayem A, Oda H, Hori K and Zhao Q 2001 Paleocurrent analysis for late Pleistocene-Holocene incised-valley fill of the Yangtze delta, China by using anisotropy of magnetic susceptibility data; Mar. Geol. 176 175-189.

Lowrie W and Heller E 1982 Magnetic properties of marine limestones; Rev. Geophys. Space Phys. 20 171-192.

Lowrie W and Hirt A M 1987 Anisotropy of magnetic susceptibility in the Scaglia Rossa pelagic limestone; Earth Planet Sci. Lett. 82 349-356.

Nagata T 1961 Rock magnetism, 2nd edn, Maruzen, Tokyo, $350 \mathrm{p}$.

Nagendra R, Sarvanan N, Kamala Kannan B V and Gargi Sen 2003 Petrophysical characterization of sandstone of Sillakkudi Formation, Ariyalur Group, Tamil Nadu; Indian J. Petrol. Geol. 10 49-52.

Parés J M, Hassold N J C, Rea D K and van der Pluijm B A 2007 Paleocurrent directions from paleomagnetic reorientation of magnetic fabrics in deep-sea sediments at the Antarctic peninsula Pacific margin (ODP Sites 1095, 1101); Mar. Geol. 242 261-269.

Park C K, Doh S J, Suk D W and Kim K H 2000 Sedimentary fabric on deep-sea sediments from KODOS area in the Eastern pacific; Mar. Geol. 171 115-126.

Piper J D A, Elliot M T and Kneller B C 1996 Anisotropy of magnetic susceptibility in a Paleozoic Flysch basin: The Windermere Supergroup, northern England; Sedim. Geol. $106235-258$.

Ramasamy S, Ramachandran A, Velmurugan K, David Lalhmingliana Chawngthu, Bhuvaneswari S and Suresh Gandhi, M 2012 Sedimentological studies of Kallamedu Formation in Ariyalur area, Tamil Nadu, India; Int. J. Geol. Earth Environ. Sci. 2 218-234.

Ramkumar M 2001 Sedimentary structures and depositional conditions of the Kallankurichchi Formation (Lower Maastrichtian), South Indian Cretaceous sequence; J. Indian Assoc. Sediment. 20 85-96.

Ramkumar M 2004 Lithology, petrography, microfacies, environmental history and hydrocarbon prospects of the Kallankurichchi Formation (Upper Cretaceous, Ariyalur Group, south India); Palaeont. Stratigr. Facies. 12 $77-100$.

Rangaraju M K, Agarwal A and Prabhakar K N 1993 Tectonostratigraphy, structural style, evolutionary model and hydrocarbon prospects of the Cauvery Palar basins of India; Indian Petrol. Publishers, Dehradun, 1 371-398.

Rathi G, Sangode S J, Rohtash Kumar and Sumit K Ghosh 2007 Magnetic fabrics under high-energy fluvial regime of 
the Himalayan Foreland Basin, NW Himalaya; Curr. Sci. 92(7) 933-944.

Rees A I 1961 The effect of water current in the magnetic remanence and anisotropy of susceptibility of some sediments; Geophys. J. 5 235-251.

Rees A I 1965 The use of anisotropy of magnetic susceptibility in the estimation of sedimentary fabric; Sedimentology $4257-271$.

Rochette P and Filliong G 1988 Identification of multicomponent anisotropies in rocks using various field and temperature values in a cryogenic magnetometers; Phys. Earth Planet. Int. 51 379-386.

Rochette P, Jackson M and Aubourg C 1992 Rock magnetism and the interpretation of anisotropy of magnetic susceptibility; Rev. Geophys. 30 209-226.

Sangode S J 2001 Application of magnetic fabric studies in an ancient fluvial sequence of NW Himalaya; Curr. Sci. 81(1) $66-71$.

Schieber J and Ellwood B B 1993 Determination of basin wide paleocurrent patterns in a shale succession from anisotropy of magnetic susceptibility (AMS): A case study of the Mid-Proterozoic Newland Formation, Montana; J. Sedim. Petrol. 63 878-880.
Stacey F D, Joplin G and Lindsay J 1960 Magnetic anisotropy and fabric of some foliated rocks from SE Australia; Geophys. Pura. Appl. 47 30-40.

Sundaram R, Henderson R A, Ayyasami K and Stilwell J D 2001 A lithostratigraphic revision and paleoenvironmental assessment of the Cretaceous System exposed in the onshore Cauvery basin, southern India; Cretaceous Res. 22 743-762.

Taira A 1989 Magnetic fabric and depositional processes in sedimentary facies in the Active Plate Margin, Tokyo; Terra Scientific Publishing, pp. 44-77.

Tarling D H and Hrouda F 1993 The Magnetic Anisotropy of Rocks; Chapman and Hall, London, 213p.

Tewari A, Malcom B, Hart and Watkinson M P 1996 A revised lithostratigraphy classification of the Cretaceous rocks of the Trichinopoly district, Cauvery basin, southeast India; Contrs XV Indian Colloq. Micropal. Strat., Dehradun, pp. 789-800.

Veloso E E, Anma R, Ota T, Komiya T, Kahashuma S and Yamazaki T 2007 Paleocurrent patterns of the sedimentary sequence of the aitao ophiolite constrained by anisotropy of magnetic susceptibility and paleomagnetic analysis; Sedim. Geol. 201 446-460. 